\title{
Developing EFL Reading and Writing Skills Through Using a Cloud-Based Collaborative Blended Learning Program A Research Paper
}

\section{By}

\author{
Samah Mohamed Abd El Samad Ramadan \\ An Assistant Lecturer at Mansoura Higher Institute \\ for Engineering and Technology
}

\section{Supervisors}

\author{
Prof. Badran Abdel-Hamead Hassan \\ Dr. Reda Abdel Razek Gabr \\ Professor of Curriculum and \\ Instruction TEFLFaculty of Education, \\ Mansoura University \\ Lecturer of Educational \\ PsychologyFaculty of \\ Dr. Rehab Hamadtoh Abu-Alghait Gohar \\ Associate professor of Curriculum and Instruction TEFL \\ Faculty of Education, Mansoura University
}

Journal Of The Faculty Of Education- Mansoura University

No. 111 - July. 2020 


\title{
Developing EFL Reading and Writing Skills Through Using a Cloud-Based Collaborative Blended Learning Program
}

\author{
A Research Paper
}

\begin{abstract}
This study aimed at developing primary stage pupils' EFL reading and writing skills through using a cloud based collaborative blended learning program. To fulfill this purpose, two instruments were constructed; a pre-post EFL reading test and a pre - post writing test followed by a writing rubric. The participants of the study were 50 pupils selected from the fifth-grade primary stage pupils at Mansoura College International Language Schools in Mansoura. The study adopted the quasi-experimental design using two groups: the experimental group was taught through the proposed cloud based collaborative blended learning program while the control group studied through the regular instructional methods. Results of the study revealed that the experimental group pupils' EFL reading and writing skills were significantly developed and they outperformed their control group counterparts in their performance on these targeted skills. It was recommended that cloud based blended learning should be used in EFL teaching to develop EFL reading and writing skills and other language skills. In addition, EFL learners should be provided with reading and writing courses in which cloud based collaborative blended learning is employed.

Key words: Reading Skills -Writing Skills - Cloud based Learning-Blended Learning - Collaborative Learning - Collaborative Blended Learning.

\section{Introduction and background}

EFL teaching and learning ensure the use of four language skills. There is a close relation between the four skills reading, writing, speaking and listening, as a reading activity may lead to a discussion from which a piece of writing may be involved. Writing, which is affected by reading, helps learners to communicate their ideas effectively and to reinforce the grammar and vocabulary they are learning in class.

Reading has an essential role in EFL learning as it helps learners to gain information about different cultures and customs. Cline, Johnstone and King (2006) considered reading as a constructive process in which the learner decodes and derives the meaning from the text. In addition, Nunan (2003) stated that through reading process readers and writers interact via text. This reflects that readers extract meaning from the text and reconstruct it by combining information existed in the text and their prior knowledge. Tompkins (2006) represented the process of reading through five stages; pre-reading, reading, responding, exploring and applying.
\end{abstract}


Some researchers such as Al-Mahdi (2008), Bahlool (2013) and Chellamani (2013) researched the impact of developing learners' EFL reading skills in different stages through using different reading strategies. Results of these studies revealed the existence of general weakness in learners' EFL reading skills in all levels. Those studies provided valuable information indicating that pupils' EFL reading skills could be developed through new strategies and techniques.

Writing is also one of the major English language skills which are affected by learners' reading skills. Writing is regarded as the visual presentation of language which helps learners to communicate and understand the relation between the parts of the language and how they go together. In addition, many learners learn and remember more through the written words. Writing can be a powerful instrument of thinking because it provids learners with a mean of gaining control over their thoughts. It shaps their perception of themselves and of the world (Lindsay, 2000 and Millrood, 2001).

Some researchers such as Bassett, Devine, Perry and Rueth, (2001), Gouty and Lid (2002), Hopkins (2002), Kowalewski (2002), Masood (2005), Naeem (2007), Selim (2008) and Abu Armana (2011) focused on developing learners' EFL writing skills in different stages through using suggested programs. Their studies revealed the existence of weaknesses in learners' EFL writing skill in all levels. They also suggested using programs for developing learners' EFL writing skills (e.g. authentic materials, personalized activities and remedial program)

According, the current study proposed a cloud based collaborative blended learning program for developing primary stage pupils' EFL reading, writing skills. This program was based on the principles of the social constructivism theory which indicated that learning is an active process where learners discover and construct their principles, concepts and facts for themselves. This theory emphasizes reciprocal teaching, peer collaboration, web quests, anchored instruction and other methods that involved learning with others. In addition, it introduced instructors as facilitators not as teachers (Bauersfeld, 1995; Shunk,2000 and Christie,2005).

Cloud based collaborative blended learning program

The need to improve English teaching and learning experiences motivated researchers to develop modern models such as blended learning. Cloud based blended learning, in particular, combins the strengths of both traditional classroom and online approaches for teaching and learning. 
Blended learning means a combination of online and face-to-face tutoring. As Graham (2005) maintained, this could mean using the best of the best online learning to enable classroom activities to be active and engaging learning experiences. The aim was to encourage learners to be active participants in their learning processes rather than passive recipients by using online technologies to enable or support learning activities that continue outside the lecture hall, classroom or lab (extra-curricular) and encourage them to arrive in class well prepared. Some studies confirmed the advantages of blended EFL learning such as Oblender (2002), Gamble (2005) and Milheim (2006). These studies revealed that blended learning leads to expanding and improving learners' learning experiences. They also revealed some of the advantages of blended learning like; immediate feedback for learners, face-to-face interaction with the teacher during learning, and the flexibility of handling different content subjects according to the available circumstances.

Some other studies had examined learners' perception of blended learning when writing in English. For example, Miyazoe and Anderson (2010), Larsen (2012), So and Lee (2013), Ho and Savignon, (2013) and Liu (2013). These studies proved the effectiveness of using theblended learning approach in improving EFL learners' writing skill at various academic levels. These studies concluded that learners mostly have positive perception towards the usefulness of blended learning in improving their writing. Results also showed that blended learning hadhelped increase social interaction among the learners, aided them to be more motivated and autonomous learners,decreased their communication anxiety and enhanced their EFL writing skill. In addition, Wu (2017) proved the effectiveness of blended learning strategy for professional English course in a cloud learning environment in improving student's learning performance and promoting their satisfaction with professional English course.

Mell and Grance (2011) and Carroll, Merwe and Kotzé (2011) defined cloud based leaning as a model for enabling convenient, on-demand network access to a shared pool of configurable computing resources (e.g., networks, servers, storage, applications, and services) that could be rapidly provisioned and released with minimal management effort or service provider interaction. Could based learning involves hosting information and communication technology (ICT), infrastructure software applications and other computing services into cloud servers and being accessed via the internet. The institutions could only pay for services based on usage the same way as utility services, such as water, electricity, gas, and telephony. 
By migrating blended learning services to the cloud, institutions stand to overcome the cost of procuring, hosting and managing information and communication technology (ICT) infrastructure in their premise (Mokhtar, Ali, Al-Sharafi, and Aborujilah, 2013). However, Sultan (2010) viewed that the decision to migrate blended learning computing services into the cloud depends on institutional awareness of the benefits as well as challenges associated with cloud services. There are different cloud based tools that could enhance learners' collaboration to positively affect their language learning. More recently, Khampusaen(2014) indicated that the best practices for teaching English language could be achieved through collaborative could based learning tools.

Collaborative learning is an instructional method in which pupils are teamed together. Collaborative learning has several advantages such as increasing self-esteem and motivation among learners, improving complex and cognitive thinking, creating positive feelings among learners and about school, and making responsible learners (Jacobs, Power and Loh, 2002). In addition, Maheady, Harper, Mallette, and Karnes (2004) proved the effect of collaborative learning on learners' achievement. The result of this research indicated that elementary school learners learn better when they teach one another than they do in completely teacher-directed classrooms. With regard to Nakatsukasa (2009) and Srijongjai (2013) collaborative feedback activities are very effective when they are conducted in a blended learning setting. Findings indicated that learners have positive perception towards collaborative feedback activities used in face-to-face and online environments.

Collaborative blended learning (CBL) according to Vygotsky's (1978) social constructivism - one of the roots of CBL stressed on learners working together in online learning environments to create new knowledge collaboratively and authentically (Sharpe, Benfield, Roberts, and Francis, 2006). Doolan et al. (2006), echoing Vygotsky, suggested that CBL provided the opportunity for interaction in the form of learner-to-learner support, enabling learners to share ideas and provide feedback to each other on learning-related activities in diverse locations. CBL offers opportunities for all learners to participate actively in critical reflection and discourse, and contribute to a flexible and sustainable community of inquiry (Vaughan, 2010 and Garrison, 2011). CBL has considerable communicative potential with asynchronous interaction (Chan, 2012; Garrison and Anderson,

2003; Jonassen and Kwon, 2001; Jung, Choi, Lim, and Leem, 2002; Zhu,2012).CBLcan provide learners with the opportunity to practice conflict 
negotiation and consensus building as learners exchange ideas, share perspectives and arguments, and use previous knowledge or experiences to solve problems in group work activities (Dewiyanti et al., 2007).

To conclude, in light of the previously mentioned review of literature, it becomes vital for teachers to pay attention to the growing needs of the pupils to read and write correctly. Hence, this study was established with an aim of developing primary stage pupils' EFL reading and writing skill using modern technology. Cloud based collaborative blended learning program is able to encourage the pupils to read correctly and write perfectly. Thus, the current study aimed at investigating the effect of using a cloud based collaborative blended learning program on develop primary stage pupils' EFL reading and writing skills.

\section{The pilot study}

A pilot study was conducted to assess the current level of EFL reading and writing skills of 25 fifth grade primary pupils from Mansoura College International Language Schools (MCILS). The following tables reports the pilot results.

Table (1)

Results of the pilot study EFL reading test

\begin{tabular}{|c|c|c|c|c|c|}
\hline School & $\mathbf{N}$ & Reading Skills & $\begin{array}{l}\text { Mean } \\
\text { Score }\end{array}$ & SD & rcenta \\
\hline \multirow{6}{*}{$\begin{array}{l}\text { Mansoura } \\
\text { College } \\
\text { International } \\
\text { Language } \\
\text { Schools }\end{array}$} & \multirow{6}{*}{2525} & Scanning & 1.31 & 0.535 & $61.5 \%$ \\
\hline & & Skimming & 0.98 & 0.561 & $\% 60.2$ \\
\hline & & Juessing the meaning of new vocabulary & 0.97 & 0.507 & $\% 59$ \\
\hline & & $\begin{array}{l}\text { Prediction. } \\
\end{array}$ & 1.02 & 0.601 & $\% 58$ \\
\hline & & Summarizing the Text & 1.12 & 0.623 & $\% 54$ \\
\hline & & Total & 5.4 & 0.0572 & $\% 58.6$ \\
\hline
\end{tabular}

Results in Table (1) show that the percentage of pupils' score on the Reading Skill Test is (\%58.6). This means that those pupils need more improvement to to develop their EFL reading skills.

Table (2)

Results of the Pilot Study EFL Writing Test

\begin{tabular}{|c|c|c|c|c|c|}
\hline School & $\mathrm{N}$ & Writing Skills & $\begin{array}{l}\text { Mean } \\
\text { score }\end{array}$ & SD & Percentage \\
\hline \multirow{6}{*}{$\begin{array}{l}\text { Mansoura } \\
\text { College } \\
\text { International } \\
\text { Language } \\
\text { Schools }\end{array}$} & \multirow{6}{*}{25} & Use appropriate vocabulary & 1.8 & 0.763 & $56 \%$ \\
\hline & & Use grammar properly. & 1.76 & 0.523 & $\% 56$ \\
\hline & & Use Punctuation marks correctly. & 1.92 & 0.702 & $\% 64$ \\
\hline & & Have correct spelling. & 1.72 & 0.707 & $\% 48$ \\
\hline & & Coherence & 1.8 & 0.701 & $\% 56$ \\
\hline & & Total & 9 & 0.701 & $\% 60$ \\
\hline
\end{tabular}


Results in Table (2) show that the percentage of pupils' score on the Writing Skills Test is (\%60). This means that those pupils need more improvement to be better and to develop their EFL writing skills.

Statement of the problem

Based on the previous review, the researcher's experience as a teacher for about 14 years and the pilot study results, Fifth grade primary stage pupils need to develop their EFL reading and writing skills. Thus, the current study investigated the effect of using a cloud based collaborative blended learning program on developing primary stage pupils' EFL reading and writing skills.

\section{Questions}

The present study attempted to answer the following main question:

"To what extent can a Cloud Based Collaborative Blended Learning Program develop fifth grade primary stage pupils' EFL reading and writing skills?"

For research purposes, the following sub-questions were derived from the main question.

1. What are the components of the proposed cloud based collaborative blended learning program required for developing fifth grade primary stage pupils' EFL reading and writing skills and their self- efficacy?

2. What is the effectiveness of using a cloud based collaborative blended learning program in developing fifth grade primary stage pupils' EFL reading skills?

What is the effectiveness of using a cloud based collaborative blended learning program in developing fifth grade primary stage pupils' EFL writing skills?

Purpose

The present study aimed at:

Developing 5th grade primary stage pupils' EFL reading skills and writing skills through using a proposed cloud based collaborative blended learning program.

Hypotheses

This study tested the following hypotheses:

1. There is a statistically significant difference at the 0.05 level between the mean rank of the control group and that of the experimental one on the post administration of the EFL reading skills test in favor of the experimental group.

2. There is a statistically significant difference at the 0.05 level between the mean rank of the experimental group on the pre-post administration 
of the EFL reading skills test in favor of the post one.

3. There is a statistically significant difference at the 0.05 level between the mean rank of the control group and that of the experimental one on the post administration of the EFL writing skills test in favor of the experimental group.

4. There is a statistically significant difference at the 0.05 level between the mean rank of the experimental group pupils on the pre-post administration of the EFL writing skills test in favor of the post one.

$\underline{\text { Method }}$

Design

The study adopted the quasi-experimental design using two groups: experimental and control. The experimental group received the target four modules by using the proposed cloud based collaborative blended learning program, while the control group received them by using regular instruction. Both groups received the pre- post reading and writing tests to assess their taregeted EFL reading and writing skills.

\section{Participants}

Participants of the study were fifth grade primary stage pupils at Mansoura College International Language Schools. They were trained on computer and internet skills in their fourth and fifth grades; thus, it was expected that they would be qualified to use Google Cloud tools (Gsuite such as; Google sites, Google translator, Google Docs, Google Calendar, Google Forms, Gmail and hangout) through which the proposed cloud based collaborative blended learning program was presented. Participants were divided into two groups: control and experimental, and each group consisted of 20 pupils.The experimental group pupils were taught through the proposed cloud based collaborative blended learning program, while the control group pupils studied through regular instruction as planned by the Ministry of Education in Egypt.

The following instruments were designed and used:

1. A pre - post EFL reading skills test

2. A pre-post EFL writing skills test followed by a writing scoring rubric.

\section{Results and Discussions}

The results of the study were statistically analyzed test in terms of its hypotheses and they were discussed in the light of the theoretical background and related studies. Results of the study were reported as follows:

Testing the first hypothesis 
The first hypothesis stated that "There is a significant difference at 0.05 level between the mean ranks of the control group and the experimental group pupils on the post administration of the EFL reading skills test in favor of the experimental group." Mann-Whitney Test for independent was used to compare the difference between the mean ranks of the experimental and control group pupils in the EFL reading skills test after implementing the proposed cloud based collaborative learning program.

Table (3)

Results of the control and experimental groups on the post administration of the EFL reading skills test

\begin{tabular}{|c|c|c|c|c|c|c|}
\hline $\begin{array}{l}\text { Reading } \\
\text { Skills }\end{array}$ & Group & $\mathbf{N}$ & $\begin{array}{l}\text { Mean } \\
\text { Rank }\end{array}$ & $\begin{array}{l}\text { Sum of } \\
\text { Ranks }\end{array}$ & $\begin{array}{c}\text { Mann- } \\
\text { Whitney U }\end{array}$ & Sig. (2-tailed \\
\hline \multirow[t]{3}{*}{ Skimming } & Control & 25 & 13.12 & 328.00 & 3 & \multirow{3}{*}{$\begin{array}{c}\text { Significant at } \\
0.05\end{array}$} \\
\hline & Experiment & 25 & 37.88 & 947.00 & & \\
\hline & Total & 50 & & & & \\
\hline \multirow[t]{3}{*}{ Scanning } & Control & 25 & 13.10 & 327.50 & 2.5 & \multirow{3}{*}{$\begin{array}{c}\text { Significant at } \\
0.05\end{array}$} \\
\hline & Experiment & 25 & 37.90 & 947.50 & & \\
\hline & Total & 50 & & & & \\
\hline \multirow{3}{*}{$\begin{array}{l}\text { Guessing } \\
\text { the } \\
\text { meaning of } \\
\text { new vocab. }\end{array}$} & Control & 25 & 13.62 & 350.50 & 15.5 & \multirow{3}{*}{$\begin{array}{c}\text { Significant at } \\
0.05\end{array}$} \\
\hline & Experiment & 25 & 37.38 & 934.50 & & \\
\hline & Total & 50 & & & & \\
\hline \multirow{3}{*}{$\begin{array}{l}\text { Making } \\
\text { Prediction }\end{array}$} & Control & 25 & 15.00 & 375.00 & 50 & \multirow{3}{*}{$\begin{array}{c}\text { Significant at } \\
0.05\end{array}$} \\
\hline & Experiment & 25 & 36.00 & 900.00 & & \\
\hline & Total & 50 & & & & \\
\hline \multirow{3}{*}{$\begin{array}{c}\text { Summarizi } \\
\text { ng a text }\end{array}$} & Control & 25 & 13.16 & 329.00 & 4 & \multirow{3}{*}{$\begin{array}{c}\text { Significant at } \\
0.05\end{array}$} \\
\hline & Experiment & 25 & 37.84 & 946.00 & & \\
\hline & Total & 50 & & & & \\
\hline \multirow[t]{3}{*}{ Total } & Control & 25 & 13.00 & 325.00 & 0 & \multirow{3}{*}{$\begin{array}{c}\text { Significant at } \\
0.05\end{array}$} \\
\hline & Experiment & 25 & 38.00 & 950.00 & & \\
\hline & Total & 50 & & & & \\
\hline
\end{tabular}

Mann-Whitney U values for the EFL reading sub-skills are (3, 2,5, 15.5, 50 and 4 respectively) and they all are significant at the 0.05 level. This indicates that there is a statistically significant difference between the mean ranks of the control and experimental groups pupils' at (0.05) level in the post administration of the EFL reading skills test in favor of the experimental group. These differences are due to using the proposed cloud based collaborative blended learning program. Thus, the experimental group pupils outperformed their counterparts of the control group who studied through the regular exercises presented in the pupils' book and the work book. Therefore, the first hypothesis of the study is verified and accepted.

Testing the second hypothesis

Results of testing the second hypothesis stated that "There is a statistically significant difference at the 0.05 level between the mean ranks 
of the experimental group on the pre- post administration of the EFL reading skills test in favor of the post one." Wilcoxon Signed Ranks-Test for dependent samples was used to compare the difference between the mean ranks of the experimental pupils in the EFL reading skills test before and after administering the proposed cloud based collaborative learning program.

Table (4)

Results of the Experimental Group on the Pre-post- Administration of the EFL Reading Skills Test

\begin{tabular}{|c|c|c|c|c|c|c|}
\hline Reading Skills & Ranks & $\mathbf{N}$ & Mean Rank & Sum of Ranks & $\mathbf{Z}$ & Sig. (2-tailed) \\
\hline \multirow{4}{*}{ Skimming } & Negative Ranks & 0 & .00 & .00 & \multirow{4}{*}{4.405} & \multirow{4}{*}{$\begin{array}{l}\text { Significant at } \\
0.05\end{array}$} \\
\hline & Positive Ranks & 25 & 13 & 325 & & \\
\hline & Ties & 0 & & & & \\
\hline & Total & 25 & & & & \\
\hline \multirow{4}{*}{ Scanning } & Negative Ranks & 0 & .00 & .00 & \multirow{4}{*}{4.33} & \multirow{4}{*}{$\begin{array}{c}\text { Significant at } \\
0.05\end{array}$} \\
\hline & Positive Ranks & 24 & 12.5 & 300 & & \\
\hline & Ties & 1 & & & & \\
\hline & Total & 25 & & & & \\
\hline \multirow{4}{*}{$\begin{array}{l}\text { Guessing the } \\
\text { meaning of new } \\
\text { vocab. }\end{array}$} & Negative Ranks & 0 & .00 & .00 & \multirow{4}{*}{4.67} & \multirow{4}{*}{$\begin{array}{c}\text { Significant at } \\
0.05\end{array}$} \\
\hline & Positive Ranks & 25 & 13 & 325 & & \\
\hline & Ties & 0 & & & & \\
\hline & Total & 25 & & & & \\
\hline \multirow{4}{*}{ Making Prediction } & Negative Ranks & 0 & .00 & .00 & \multirow{4}{*}{4.299} & \multirow{4}{*}{$\begin{array}{c}\text { Significant at } \\
0.05\end{array}$} \\
\hline & Positive Ranks & 23 & 12 & 276 & & \\
\hline & Ties & 2 & & & & \\
\hline & Total & 25 & & & & \\
\hline \multirow{4}{*}{$\begin{array}{c}\text { Summarizing a } \\
\text { Text }\end{array}$} & Negative Ranks & 0 & .00 & .00 & \multirow{4}{*}{4.40} & \multirow{4}{*}{$\begin{array}{c}\text { Significant at } \\
0.05\end{array}$} \\
\hline & Positive Ranks & 25 & 13 & 325 & & \\
\hline & Ties & 0 & & & & \\
\hline & Total & 25 & & & & \\
\hline \multirow{4}{*}{ Total } & Negative Ranks & 0 & 00 & 00 & \multirow{4}{*}{4.382} & \multirow{4}{*}{$\begin{array}{c}\text { Significant at } \\
0.05\end{array}$} \\
\hline & Positive Ranks & 25 & 13 & 325 & & \\
\hline & Ties & 0 & & & & \\
\hline & Total & 25 & & & & \\
\hline
\end{tabular}

Wilcoxon Z-values for the EFL reading sub-skills are (4.405, 4.33, 4.67, 4.299 and 4.40 respectively) and they all are significant at the level 0.05 . Comparing the mean ranks in the pre- post administration of the EFL reading skills test reveals that there are statistically significant differences between the mean ranks of the pre-post-administration of the EFL reading skills test in the two the domains and in the total score. These significant differences are in favor of the post-test.

The mean rank of the experimental group pupils' post-test implies that the experimental group pupils' level in overall the EFL reading skills test improved due to the proposed cloud based collaborative blended learning 
program presented via Google cloud tools (Google Sites, Gmail, Google Drive, Google Docs, Google Calendar, Google Slides, Google Forms and Google Hangout). All these tools are presented through the educational Google site (https://sites.google.com /view/smsamad) to present the target modules and the extra reading activities such as name the objects, Pictionary and guess from a sentence. This increase indicates the effect of the proposed cloud based collaborative blended learning program. Accordingly, the second hypothesis of the present study is proved and verified.

Such results of the present study show that the experimental group achieved more improvement on the post administration of the EFL reading skills test compared to the pre-test. This is consistent with Ajibade, Shamsuddin and Ahmad (2017) the result of their study showed that there were distinctive educating and learning impacts on the blended collaborative synchronous teaching; it also shows that an unforeseen form of interactions occurred in the blended collaborative communication; and then it also shows that both the face-to-face and online students accomplished comparative learning results. In addition to, Djiwandono (2018) which showed that the experimental group gained a significantly higher gain in their reading skills and vocabulary mastery. Quite probably, the online sessions had promoted more exposure to other reading texts, which in turn promoted their vocabulary mastery. The sessions may have encouraged the kinds of attitude that was vital in increasing reading comprehension.

\section{Testing the Third Hypothesis}

The third hypothesis stated that "There is a significant difference at 0.05 level between the mean ranks of the control group and the experimental group on the post administration of the EFL writing skills test in favor of the experimental group." Mann-Whitney Test for independent samples was used to compare the difference between the mean ranks of the control and experimental group pupils in the post implementation of EFL writing skills test as shown in the following Table (5). 
Table (5)

Results of the Control and Experimental Groups on the Post Administration of the EFL Writing Skills Test

\begin{tabular}{|c|c|c|c|c|c|c|}
\hline Skills & Group & $\mathbf{N}$ & $\begin{array}{l}\text { Mean } \\
\text { Rank }\end{array}$ & $\begin{array}{l}\text { Sum of } \\
\text { Ranks }\end{array}$ & $\begin{array}{c}\text { Mann- } \\
\text { Whitney U }\end{array}$ & Sig. (2-tailed) \\
\hline \multirow{3}{*}{$\begin{array}{c}\text { Use of appropriate } \\
\text { vocab. }\end{array}$} & Control & 25 & 13.00 & 325.00 & 0 & \multirow{3}{*}{$\begin{array}{c}\text { Significant at } \\
0.05\end{array}$} \\
\hline & Experiment & 25 & 38.00 & 950.00 & & \\
\hline & Total & 50 & & & & \\
\hline \multirow{3}{*}{$\begin{array}{c}\text { Use of grammar } \\
\text { properly }\end{array}$} & Control & 25 & 13.12 & 328.00 & 3 & \multirow{3}{*}{$\begin{array}{c}\text { Significant at } \\
0.05\end{array}$} \\
\hline & Experiment & 25 & 37.88 & 947.00 & & \\
\hline & Total & 50 & & & & \\
\hline \multirow{3}{*}{$\begin{array}{l}\text { Use of punctuation } \\
\text { marks correctly }\end{array}$} & Control & 25 & 13.00 & 325.00 & 0 & \multirow{3}{*}{$\begin{array}{c}\text { Significant at } \\
0.05\end{array}$} \\
\hline & Experiment & 25 & 38.00 & 950.00 & & \\
\hline & Total & 50 & & & & \\
\hline \multirow[t]{3}{*}{ Have correct spelling } & Control & 25 & 13.25 & 330.00 & 5 & \multirow{3}{*}{$\begin{array}{c}\text { Significant at } \\
0.05\end{array}$} \\
\hline & Experiment & 25 & 37.80 & 945.00 & & \\
\hline & Total & 50 & & & & \\
\hline \multirow[t]{3}{*}{ Coherence and Cohesion } & Control & 25 & 13.10 & 327.50 & 2.5 & \multirow{3}{*}{$\begin{array}{c}\text { Significant at } \\
0.05\end{array}$} \\
\hline & Experiment & 25 & 37.90 & 947.50 & & \\
\hline & Total & 50 & & & & \\
\hline \multirow[t]{3}{*}{ Total } & Control & 25 & 13.00 & 325.00 & 0 & \multirow{3}{*}{$\begin{array}{c}\text { Significant at } \\
0.05\end{array}$} \\
\hline & Experiment & 25 & 38.00 & 950.00 & & \\
\hline & Total & 50 & & & & \\
\hline
\end{tabular}

Table(5)indicates that there is a significant difference at (0.05) between the mean ranks of the control and experimental groups in the post administration of the EFL writing skills test in favor of the experimental group.

Comparing the mean ranks of the control and experimental group on the post administration of the EFL writing skills test shows that the experimental group pupils' mean ranks in the post EFL writing skills test are $(38,37.88,38,37.80$ and 37.90 respectively), while the control group's mean ranks in the post EFL writing skills test are (13,13.12,13,13.20 and 13.10 respectively). These values indicate the significant development of the experimental group pupils concerning their EFL writing sub-skills over the control group. This implies the effect of the proposed cloud based collaborative blended learning program on fifth grade primary stage pupils' EFL writing skills. Thus, the third hypothesis is verified and accepted. 


\section{Testing the Fourth Hypothesis}

The fourth hypothesis stated that " There is a significant difference at 0.05 level between the mean ranks of the experimental group pupils on the pre-post administration of the EFL writing skills test in favor of the post one." Wilcoxon Signed Ranks Test for dependent samples was used to compare the difference between the mean ranks of the experimental in the pre-post EFL writing skills test.

Table (6)

Results of the Experimental Groups on the Pre- post Administration of The EFL Writing Skills Test

\begin{tabular}{|c|c|c|c|c|c|c|}
\hline Skill & Ranks & $\mathbf{N}$ & Mean Rank & $\begin{array}{l}\text { Sum of } \\
\text { Ranks }\end{array}$ & $\mathbf{Z}$ & $\begin{array}{c}\text { Sig. } \\
\text { (2-tailed) }\end{array}$ \\
\hline \multirow{4}{*}{$\begin{array}{c}\text { Use of } \\
\text { appropriate } \\
\text { vocab. }\end{array}$} & Negative Ranks & 0 & .00 & .00 & \multirow{4}{*}{4.41} & \multirow{4}{*}{$\begin{array}{l}\text { Significan } \\
\text { at } 0.05\end{array}$} \\
\hline & Positive Ranks & 25 & 13 & 325 & & \\
\hline & Ties & 0 & & & & \\
\hline & Total & 25 & & & & \\
\hline \multirow{4}{*}{$\begin{array}{l}\text { Use of } \\
\text { grammar } \\
\text { properly }\end{array}$} & Negative Ranks & 0 & .00 & .00 & \multirow{4}{*}{4.42} & \multirow{4}{*}{$\begin{array}{l}\text { Significant } \\
\text { at } 0.05\end{array}$} \\
\hline & Positive Ranks & 25 & 13 & 325 & & \\
\hline & Ties & 0 & & & & \\
\hline & Total & 25 & & & & \\
\hline \multirow{4}{*}{$\begin{array}{c}\text { Use of } \\
\text { punctuation } \\
\text { marks } \\
\text { correctly }\end{array}$} & Negative Ranks & 0 & .00 & .00 & \multirow{4}{*}{4.43} & \multirow{4}{*}{$\begin{array}{l}\text { Significant } \\
\text { at } 0.05\end{array}$} \\
\hline & Positive Ranks & 25 & 13 & 325 & & \\
\hline & Ties & 0 & & & & \\
\hline & Total & 25 & & & & \\
\hline \multirow{4}{*}{$\begin{array}{l}\text { Have correct } \\
\text { spelling }\end{array}$} & Negative Ranks & 0 & .00 & .00 & \multirow{4}{*}{4.44} & \multirow{4}{*}{$\begin{array}{l}\text { Significan } \\
\text { at } 0.05\end{array}$} \\
\hline & Positive Ranks & 25 & 13 & 325 & & \\
\hline & Ties & 0 & & & & \\
\hline & Total & 25 & & & & \\
\hline \multirow{4}{*}{$\begin{array}{l}\text { Coherence } \\
\text { and } \\
\text { Cohesion }\end{array}$} & Negative Ranks & 0 & .00 & .00 & \multirow{4}{*}{4.41} & \multirow{4}{*}{$\begin{array}{l}\text { Significant } \\
\text { at } 0.05\end{array}$} \\
\hline & Positive Ranks & 25 & 13 & 325 & & \\
\hline & Ties & 0 & & & & \\
\hline & Total & 25 & & & & \\
\hline \multirow{4}{*}{ Total } & Negative Ranks & 0 & .00 & .00 & \multirow{4}{*}{4.38} & \multirow{4}{*}{$\begin{array}{l}\text { Significan } \\
\text { at } 0.05\end{array}$} \\
\hline & Positive Ranks & 25 & 13 & 325 & & \\
\hline & Ties & 0 & & & & \\
\hline & Total & 25 & & & & \\
\hline
\end{tabular}

As Table (6) illustrates, Wilcoxon Z-values for the EFL writing subskills are $(4.41,4.42,4.43,4.44$ and 4.41 respectively) and they are significant at level (0.05). Comparing the mean ranks in the pre- post administration of the EFL writing skills test indicates the significant 
difference between the mean ranks before and after the administration of the EFL writing skills test is in favor of the post one.

The greater mean rank of the experimental group's post-test implies that the experimental group pupils' level in overall EFL writing skills test developed due to the proposed cloud based collaborative blended learning program and the extra writing activities such as guessing word game and story chains. This increase indicates the effect of the proposed cloud based collaborative blended learning program.

Such results of the present study show that the experimental group achieved more development on the post administration of the EFL writing skills test compared to the pre-test. This result is consistent with Miyazoe and Anderson (2010), Larsen (2012), So and Lee (2013), Ho and Savignon, (2013) and Liu (2013). These studies proved the effectiveness of using the blended learning approach in improving EFL learners' writing skill at various academic levels. These studies concluded that students mostly have positive perception towards the usefulness of blended learning in improving their writing. Results also showed that blended learning had helped increase social interaction among the students, aided them to be more motivated and autonomous learners, decreased their communication anxiety and enhanced their EFL writing skill. Accordingly, the fourth hypothesis of the present study is proved and verified.

\section{The Effect Size of the Proposed Program}

First, Pearson Correlation squared (r) was estimated to measure the effect size of the proposed cloud based collaborative blended learning program on the pupils' EFL reading and writing skills. Pearson Correlation squared ( $r$ ) was estimated after calculating the $Z$ value. The formula was: $r$ $=\mathrm{z} / \sqrt{ } \mathrm{N}$. The following Table () illustrates the effect size of the proposed cloud based collaborative blended learning program on the experimental group pupils' EFL reading skills.

Table (7) Level of the Effect Size of the Proposed Program on the Pupils' EFL Reading Skills

\begin{tabular}{|c|c|c|c|c|c|c|}
\hline $\begin{array}{c}\text { Independent } \\
\text { variable }\end{array}$ & \multicolumn{2}{|c|}{ Domains of the dependent variable } & $\mathbf{Z}$ & $\mathbf{N}$ & $\begin{array}{l}\text { Value } \\
\text { of }(\mathbf{r})\end{array}$ & $\begin{array}{c}\text { Level of } \\
\text { Effect Size }\end{array}$ \\
\hline \multirow{6}{*}{$\begin{array}{l}\text { The Proposed } \\
\text { Cloud based } \\
\text { Collaborative } \\
\text { Blended } \\
\text { Learning } \\
\text { program }\end{array}$} & \multirow{6}{*}{ 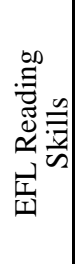 } & Skimming & 4.405 & \multirow{6}{*}{25} & 0.881 & \multirow{6}{*}{ High } \\
\hline & & Scanning & 4.33 & & 0.866 & \\
\hline & & $\begin{array}{l}\text { Guess the meaning of new } \\
\text { vocab }\end{array}$ & 4.67 & & 0.934 & \\
\hline & & Making prediction & 4.299 & & 0.86 & \\
\hline & & Summarizing a text & 4.40 & & 0.88 & \\
\hline & & Total & 4.382 & & 0.876 & \\
\hline
\end{tabular}


Results in Table (7) illustrate the squared (r) for each EFL reading sub-skill. The effect size (r) values are $(0.881,0.886,0.934,0.86$ and 0.88 respectively). It is obvious that all of these values exceeded $(0.50)$ which reflects a high effect size for all the target EFL reading sub-skills. The effect size can be indicated as follows:

The effect size values which ranged between (0.86 and 0.934)) for the target EFL reading sub-skills points to the high impact of the experimental treatment in this study. The proposed cloud based collaborative blended learning program presented through the educational google site (https://sites.google.com/view/smsamad) developed fifth grade primary stage pupils' EFL reading skills magnificently.

Second, the value of squared (r) was estimated to determine the effect size of the proposed cloud based collaborative blended learning program on the pupils' EFL writing skills. Results are illustrated in the following Table (8).

Table (8)

Level of the Effect Size of the Proposed Program on the Pupils' EFL Writing Skills

\begin{tabular}{|c|c|c|c|c|c|c|}
\hline Independent Variable & Dol & $\begin{array}{l}\text { ins of the dependent } \\
\text { variable }\end{array}$ & $\mathbf{Z}$ & $\mathbf{N}$ & $\begin{array}{l}\text { Value } \\
\text { of }(\mathbf{r})\end{array}$ & $\begin{array}{c}\text { Level of } \\
\text { Effect Size }\end{array}$ \\
\hline \multirow{6}{*}{$\begin{array}{c}\text { The Proposed Cloud } \\
\text { based Collaborative } \\
\text { Blended Learning } \\
\text { Program }\end{array}$} & \multirow{6}{*}{ 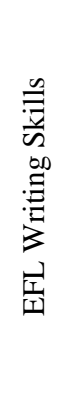 } & $\begin{array}{l}\text { Use of appropriate } \\
\text { vocab }\end{array}$ & 4.41 & \multirow{6}{*}{25} & 0.88 & \multirow{6}{*}{ High } \\
\hline & & $\begin{array}{c}\text { Use of grammar } \\
\text { properly }\end{array}$ & 4.42 & & 0.88 & \\
\hline & & $\begin{array}{l}\text { Use of punctuation } \\
\text { marks correctly }\end{array}$ & 4.43 & & 0.89 & \\
\hline & & Have correct spelling & 4.44 & & 0.89 & \\
\hline & & $\begin{array}{c}\text { Coherence and } \\
\text { Cohesion } \\
\end{array}$ & 4.41 & & 0.88 & \\
\hline & & Total & 4.38 & & 0.88 & \\
\hline
\end{tabular}

Results in Table (8) illustrate the value of squared (r) for each EFL writing sub-skill. The effect size squared $(\mathrm{r})$ values are $(0.88,0.88,0.89$, 0.89 and 0.88 respectively). It is obvious that all of these values exceeded (0.50) which reflects a high effect size for all the target EFL writing subskills. The effect size can be indicated as follows:

The effect size value (r) which ranged between $(0.88$ and 0.89$)$ for the target EFL writing sub-skills points to the high effect of the experimental treatment in this study. The proposed cloud based collaborative blended learning program presented through the educational google site ((https://sites.google.com/view/smsamad) developed fifth grade primary stage pupils' EFL writing skills magnificently. 


\section{Conclusion}

This study concluded that using a cloud based collaborative blended learning progam could develop primary stage pupils' EFL reading and writing skills.

\section{Recommendations}

A number of recommendations based on the results and the conclusions could be made as follows:

1. Cloud based collaborative blended learning program should be used in EFL teaching to develop learners' EFL reading and writing skills and other language skills.

2. EFL teachers should adapt cloud based collaborative learning program according to the learners' abilities and needs.

3. New research should be conducted to measure the effect of cloud based collaborative learning program on EFL learners' achievement.

4. Developing pupils' EFL reading ang writing skills by different Google cloud tools such as Google site, Google Docs, Gmail and Google Hangout.

Suggestions for further research

The following suggestions can be considered for further research:

1. Investigating the effectiveness of cloud based collaborative learning program in EFL classes to develop EFL other language skills such as speaking or listening.

2. Determining the impact of cloud based collaborative blended learning program on EFL classes to develop other EFL skills such as speaking or listening.

3. Further research should be conducted to determine the effectiveness of cloud based collaborative blended learning program in other educational levels.

\section{$\underline{\text { References }}$}

AbuArmana,M.(2011). The Impact of a Remedial Program on English Writing Skills of The Seventh Grade Low Achievers. Published MA Thesis, Faculty of Education, Gaza University.

Al-Mahdi, I. (2008). Reading Comprehension Skills Among Yemeni Students.Faculty of Arts, Pune University, India.

Bahlool, A. (2013). The Effect of Differentiated Instruction Strategy on Developing Ninth Graders' English Reading Comprehension Skills at Gaza UNRWA Schools. Published M.A. Thesis, the Islamic University of Gaza. 
Bassett, D. Devine, D. Perry \&Rueth, C. (2001). " Keys to Improving Writing in the Primary Grades." An Action Research Project Submitted in Partial Fulfillment of the Requirements for M.A. Degree. Illinois Chicago. Saint Xavier University. The ERIC database

Bauersfeld H. 1995. "Language Games' in the Mathematics Classroom: Their Function and Their Effects", in P. Cobb \& H. Bauersfeld (Eds.), The emergence of mathematical meaning: Interaction in classroom cultures, Hillsdale, US-NJ: Lawrence Erlbaum.

Carroll, M.; Merwe, A.; Van Der, \&Kotzé, P. (2011). Secure Cloud Computing Benefits, Risks and Controls. Information Security South Africa. 1-9.

Chan, E. S. (2012). An innovative learning approach: Integrate peer-topeer learning into blended learning. International Journal of Global Education, 1, 19-25

Chang, S. Z. (2001). "Effective Remedial Programs and Instruction". Education Journal, 171 06;85.

Chellamani, K. (2013). Activating Metacognitive Strategies on Enhancing Reading Skill among High School Students. Int J Edu Sci, 5(2): 159162.

Christie A. (2005). Constructivism and its implications for educators.

Cline, F.; Johnstone, C., and King, T. (2006). Focus group reactions to three definitions of reading (as originally developed in support of NARAP goal. Minneapolis, MN: National Accessible Reading Assessment Projects. Retrieved from: http://www.narap.info

Doolan, M. A., Thornton, H. A., \& Hilliard, A. (2006). Collaborative learning: Using technology for fostering those valued practices inherent in constructive environments in traditional education. Journal for the Enhancement of Learning and Teaching, 3,7-17

Dewiyanti, S., Brand-Gruwel, S., Jochems, W., \& Broers, N. J. (2007). Students' experiences with collaborative learning in asynchronous computer-supported collaborative learning environments. Computers in Human Behavior, 23, 496-514.

Gamble, Valerie J. (2005). The effectiveness of blended learning for the employee. Dissertation Unpublished. Fielding Graduate University.

Garrison, D. R. (2011). E-learning in the 21st century: A framework for research and practice (2nd ed.). New York, NY: Routledge.

Garrison,D.R.,\& Anderson,T.(2003).E-learning in the 21 stcentury :A framework for researchand practice. London, UK: Routledge Falmer. 
Graham, S., \& Harris, K.R.(2000).The role of self-regulation Transcription Skills in Writing and Writing Development.Educational Psychologist, 35, 3-12.

Gouty J. and Lid. S. (2002).Improving Student Writing Ability the Use of the Teacher Intervention. Published M.A. Thesis. Illinois, Chicago. Saint Xavier University. Retrieved from ERIC database.

Ho, M. C., \&Savignon, S. J. (2013). Face-to-face and computer-mediated peer review in EFL writing.CALICO journal, 24(2), 269-290.

Hopkins, C. (2002). Improving Tenth Grade Student's Five- Paragraph Essay Writing Skills Using Various Writing Strategies, Guided Assignment, and Portfolios for Growth.Nova south eastern university.The ERIC database.

Jacobs G, Power MA andLoh WI (2002). The teacher's sourcebook fo rcooperative learning: practical techniques, basic principles, and frequency asked questions. Thousand Oaks, CA: Crown Press.Kang,

Jonassen, D. H., \& Kwon H., II. (2001). Communication patterns in computer mediated versus faceto-face group problem solving. Educational Technology Research and Development, 49, 35 -51.

Jung, I., Choi, S., Lim, C., \& Leem, J. (2002). Effects of different types of interaction on learning achievement, satisfaction and participation in web-based instruction. Innovations in Education and Teaching International, 39, 153-162.

Khampusaen, D (2014). Teaching English Language withCloud -Based Tools International Journal of the Computer, the Internet and Management, 22,(1)

Shunk DH. (2000). Learning theories: An educational perspective(3rd Ed). Upper Saddle River, NJ: Prentice-Hall.

Kowalewski, E. ,(2002). Improving Student Writing in the Elementary Classrooms. Saint Xavier University. The REIC database.

Larsen, L. J. E. (2012). Teacher and student perspectives on a blended learning intensive English program writing course.Unpublished Ph.D. thesis, Iowa State University.

Lindsay, P. (2000). Teaching English Worldwide: A new practical guide to teaching English. San Francisco: Alta Book Center Publisher.

Liu, M. (2013). Blended Learning in a University EFL Writing Course: Description and Evaluation. Journal of Language Teaching and Research, 4(2), 301-309.

Lizhe,W. ( 2010) "Cloud Computing: a Perspective Study," New Generation Computing, 28, ( 2), 137-146. 
Maheady, L., Harper, G. F., Mallette, B., \& Karnes, M. (2004). Preparing preservice teachers to implement class wide peer tutoring. Teacher Education and special education, 27(4), 408-418.

Masood, A. (2005). Exploiting Authentic Materials for Developing Writing Skills.Published MA thesis, Pakistan, faculty of social sciences, Journal for the study of English linguistics, 1.( ')

Mell, P., \&Grance, T. (2011). The NIST Definition of Cloud Computing. Retrieved from http://csrc.nist.gov/publications/nistpubs/800145/SP800-145.pdf

Milheim, W. D. (2006). Strategies for the Design and Delivery of Blended Learning Courses. Educational and Delivery Technology, 46(6).

Millrood, R. (2001). Modular Course in English Teaching Methodology. Teacher Development Series.

Miyazoe, T., \& Anderson, T. (2010).Learning outcomes and students' perceptions of online writing: Simultaneous implementation of a forum, blog, and wiki in an EFL blended learning setting.System, 38(2), 185-199.http://dx.doi.org/10.1016/j.system.2010.03.006

Mokhtar, S. A., Ali, S. H. S., Al-Sharafi, A., \& Aborujilah, A. (2013). Cloud computing in academic institutions. Proceedings of the 7th International conference on Ubiquitous Information Management and Communication. 1-7.

Naeem, M. (2007).A Suggested CALL Program to Develop EFL College Learners` Mechanics of Writing.Unpublished M.A. Thesis, Faculty of Education, Kafr El; Sheikh University.

Nakatsukasa, K. (2009). The efficacy and students' perceptions of collaborative blogging in an ESL classroom. In C. A. Chapelle, H. G. Jun, \& I. Katz (Eds.), Developing and evaluating language learning materials (pp. 69-84). Ames, IA: Iowa State University.

Nunan, D. (2003). Practical English LanguageTeaching. Boston: McGraw-Hill.

Oblender, Th. (2002). A Hybrid Course Model: One Solution to the High Online DropOut Rate. Learning \& Leading with Technology, 29(6): 42-46.

Selim, M (2008). The Effectiveness of a program Based on Individualized Activities in Developing first Prep Pupils' writing skills and their Interest in English.Cairo University.Institue of Education Studies.

Sharpe, R., Benfield, G., Roberts, G., \& Francis, R. (2006). The undergraduate experience of blended e-learning: A review of UK literature and practice. London, UK: Higher Education Academy. 
So, L., \& Lee, C. H. (2013). A Case Study on the Effects of an L2 Writing Instructional Model for BlendedLearning in Higher Education. Turkish Online Journal of Educational Technology-TOJET, 12(4), 1-10.

Srijongjai, A. (2013). Collaborative feedback in a blended learning environment A case study of an EFL writingclass. The Asian Conference on Society, Education, and Technology 2013: Official Conference Proceedings Osaka, Japan.

Sultan, N. (2010). Cloud computing for education: A new dawn? InternationalJournal of Information Management, 30 (2),109-116.

Tompkins, Gail E. (2006) Literacy for the 21st Century: A Balanced Approach. (4th Ed.)Boston: Pearson

Vaughan, N. D. (2010). A blended community of inquiry approach: Linking student engagement and course redesign. The Internet and Higher Education, 13, 60-65

Vygotsky, L. (1978). Interaction between learning and development. Readings on the development of children, 23(3), 34-41.

Wu,Q.,(2017).A Blended Learning Strategy for Professional EnglishCourse in a Cloud Learning Environment. International Journal of Information and Education Technology, 7, (8).

Zhu,C.(2012).Student satisfaction, performance, and knowledge construction in online collaborative learning. Journal of Educational Technology \& Society, 15, 127-136. 